\title{
Fatty acid profile and beef quality of Nellore and Angus bulls fed whole shelled corn
}

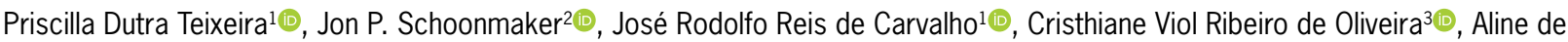 \\ Castro Rodrigues ${ }^{1}$, Luana Ruiz dos Santos ${ }^{1}$, , Marcio Machado Ladeira $^{1 *}$ (i)
}

\begin{abstract}
1 Universidade Federal de Lavras - Depto. de Zootecnia, Av. Doutor Sylvio Menicucci, s/n - 37200-900 - Lavras, MG Brasil.

2Purdue University - Dept. of Animal Science, 270 S Russell Street - 47907 - West Lafayette, IN - USA.

3Universidade Federal de Viçosa - Depto. de Zootecnia, Av. PH. Rolfs, s/n - 36570-900 - Viçosa, MG - Brasil.

*Corresponding author <mladeira@dzo.ufla.br>
\end{abstract}

Edited by: Antonio Faciola

Received August 28, 2020

Accepted January 05, 2021
ABSTRACT: This study aimed to evaluate the quality traits and fatty acid profile of beef from Nellore and Angus bulls fed whole shelled corn (WSC) and ground corn plus maize silage (GC) diets. Eighteen Nellore and 18 Angus young bulls [381 $\pm 12 \mathrm{~kg}$ initial body weight (BW) and an average age of $20 \pm 1.9$ months] were used in a completely randomized design using a $2 \times 2$ factorial arrangement and were slaughtered at a final BW of $451.5 \mathrm{~kg}$ and $545.5 \mathrm{~kg}$, respectively. Twenty-four hours after slaughter, samples of longissimus thoracis muscle were collected for the analysis of lipid oxidation, color, fatty acid profile, shear force, and cooking loss. There was no effect of diet $\times$ breed interaction on meat color, lipid oxidation, shear force, and cooking loss. Angus beef had lower shear force $(p<0.05)$ than Nellore beef and had a greater concentration of linoleic acid and polyunsaturated fatty acids (PUFA) $(p<0.01)$. Beef of bulls fed WSC tended to have greater concentration of CLA C18:2c9t11 ( $p=0.09$ ), greater concentration of CLA C18:2t10c12 ( $p=0.01)$, and PUFA ( $p=0.05)$, and consequently, higher oxidation levels. Angus bulls produced beef with greater tenderness and PUFA concentration. The results of fatty acid show a possible change in biohydrogenation when animals are fed the WSC diet, reducing lipogenesis, as this diet increases the $\mathrm{C} 18: 2 \mathrm{t} 10 \mathrm{c} 12$ content.

Keywords: Bos indicus, CLA, PUFA, corn processing, tenderness

\section{Introduction}

Production of high-quality beef and reduction of risks to human health are objectives of the beef industry to satisfy consumer demands and increase sales. Genetics and nutrition are the major factors that influence beef quality and can be thus altered during the production system. Different breeds have distinct growth patterns and, consequently, different deposition of muscle and adipose tissue, which may affect meat juiciness, flavor, and tenderness (Ladeira et al., 2014). In this sense, as the percentage of Bos indicus genes increases, meat tenderness decreases (Andrade et al., 2010; Barcellos et al., 2017). In addition, beef from breeds with lower intramuscular fat has greater concentrations of polyunsaturated fatty acid (PUFA) and lower concentrations of monounsaturated fatty acid (MUFA) (De Smet et al., 2004).

Furthermore, differences in the fatty acid profile between Bos indicus and Bos taurus may also be associated to differences in the rumen volume and gastrointestinal tract (Bressan et al., 2011; Rossato et al., 2010) and in the skeletal muscle metabolism (Ladeira et al., 2018). Bressan et al. (2016) suggested that Bos indicus cattle have a limited capacity for synthesizing $n-3$ and n-6 long-chain PUFA.

These differences between breeds can also be highly influenced by the finishing diet used (Bressan et al., 2016; Bressan et al., 2011). Some diet components can change the rumen microbial ecosystem, altering, for example, biohydrogenation. In this sense, increasing the starch supply to the rumen could reduce rumen $\mathrm{pH}$ due to rapid fermentation (Owens et al., 1998), resulting in incomplete biohydrogenation and increasing CLA C18:2t10c12 instead of C18:2c9t11 (Jenkins and
Harvatine, 2014). Moreover, the increase in C18:2t10c12 could lead to a decrease in the activity of key lipogenic enzymes (Obsen et al., 2012), reducing de novo fatty acid synthesis (Wu et al., 2011).

We hypothesized that beef from Angus bulls have greater tenderness, intramuscular fat, and SFA compared to the Nellore bulls. In addition, bulls fed a WSC diet increase CLA isomers, MUFA, and PUFA concentrations in the muscle. Therefore, this study aimed to evaluate the fatty acid profile and qualitative characteristics of beef from Nellore and Angus bulls fed a diet without forage that included WSC or a diet with a ground corn plus maize silage (GC).

\section{Materials and Methods}

The experimental procedures were approved by the Ethics and Animal Welfare Committee of the Federal University of Lavras (protocol number 016/2012).

\section{Experimental design, animals, and diets}

Eighteen Nellore and 18 Angus bulls with an average initial body weight of $359 \pm 16.9 \mathrm{~kg}$ and $392 \pm 16.9$ $\mathrm{kg}$, respectively, and an average age of $20 \pm 1.9$ months, were housed in individual pens in a completely randomized design in a $2 \times 2$ factorial arrangement ( 2 diets and 2 breeds). Experimental diets (DM basis) were: ground corn plus maize silage (GC) diet that contained $30 \%$ corn silage and $70 \%$ ground corn-based concentrate diet, and a whole shelled corn (WSC) diet containing $85 \%$ of WSC base diet with $15 \%$ soybean meal and mineral-based pelleted supplement (Table 1). The treatments were Nellore fed the GC diet, Nellore 
Table 1 - Percentage of ingredients, chemical composition, and proportion of the fatty acids of the experimental diets.

\begin{tabular}{|c|c|c|}
\hline \multirow{2}{*}{ Item } & \multicolumn{2}{|c|}{ Diets } \\
\hline & $\mathrm{GC}^{1}$ & WSC $^{2}$ \\
\hline \multicolumn{3}{|l|}{ Ingredients, $\%$ of DM } \\
\hline Whole shelled corn ${ }^{3}$ & - & 85 \\
\hline Protein and mineral supplement ${ }^{4}$ & - & 15 \\
\hline Corn silage $\mathrm{e}^{3}$ & 30 & - \\
\hline Ground corn ${ }^{3}$ & 58 & - \\
\hline Soybean meal & 10 & - \\
\hline Mineral supplement ${ }^{5}$ & 2 & - \\
\hline \multicolumn{3}{|l|}{ Nutrients, $\%$ of DM } \\
\hline Dry matter & 57.3 & 87.8 \\
\hline Crude protein & 12.7 & 14.6 \\
\hline Neutral detergent fiber & 24.0 & 11.1 \\
\hline NDF from forage & 14.7 & 0 \\
\hline Non-fiber carbohydrate ${ }^{6}$ & 56.2 & 67.1 \\
\hline Starch & 49.0 & 61.8 \\
\hline Ether extract & 2.2 & 2.6 \\
\hline Metabolizable energy, Mcal kg ${ }^{-1} \mathrm{MS}^{7}$ & 2.59 & 2.97 \\
\hline \multicolumn{3}{|l|}{ Fatty acids, $\%$ of total FA } \\
\hline Myristic, C14:0 & 0.54 & 0.17 \\
\hline Palmitic, C16:0 & 17.3 & 15.8 \\
\hline Stearic, C18:0 & 6.13 & 3.35 \\
\hline Oleic, C18:1c9 & 27.3 & 29.4 \\
\hline Linoleic, C18:2 & 42.2 & 48.3 \\
\hline Linolenic, C18:3 & 3.34 & 2.97 \\
\hline$\Sigma$ Saturated & 22.6 & 16.8 \\
\hline$\Sigma$ Unsaturated & 75.0 & 83.2 \\
\hline$\Sigma$ Monounsaturated & 28.8 & 30.9 \\
\hline$\Sigma$ Polyunsaturated & 46.2 & 52.3 \\
\hline
\end{tabular}

${ }^{1} \mathrm{GC}=$ ground corn; ${ }^{2} \mathrm{WSC}=$ whole shelled corn; ${ }^{3}$ Flint corn; ${ }^{4}$ Composition: corn, soybean meal, cottonseed meal, and soybean hulls (concentrations not provided by the manufacturer); CP: $32.0 \%$, TDN: $50.0 \%$, Ca: $45 \mathrm{~g} \mathrm{~kg}^{-1}$, Mg: $7.5 \mathrm{~g} \mathrm{~kg}^{-1}, \mathrm{P}: 11 \mathrm{~g} \mathrm{~kg}^{-1}$, Cu $104 \mathrm{mg} \mathrm{kg}^{-1}$, Zn: $344 \mathrm{mg} \mathrm{kg}^{-1}$, Se: $0.83 \mathrm{mg}$ $\mathrm{kg}^{-1}, 30,500 \mathrm{IU} \mathrm{kg}^{-1}$ of Vitamin A, 3,800 IU kg-1 of Vitamin D3, $134 \mathrm{IU} \mathrm{kg-1}$ of Vitamin $\mathrm{E}$ (Nutronbeef Grano Entero; Nutron Alimentos, Campinas, Brazil); ${ }^{5}$ Assurance levels per kilogram of product: Ca: $170 \mathrm{~g}, \mathrm{P}: 31 \mathrm{~g}$, Na: $155 \mathrm{~g}$, Zn: $2 \mathrm{mg}$, Cu: $396 \mathrm{mg}, \mathrm{Mn}: 515 \mathrm{mg}$, Co: $15 \mathrm{mg}$, l: $29 \mathrm{mg}$, Se: $5.4 \mathrm{mg}$, vitamin A: 111,000 IU, vitamin D3: 22,000 IU, vitamin E: $265 \mathrm{IU}$; ${ }^{5}$ Nonfiber carbohydrates calculated according to Sniffen et al. (1992); ${ }^{7}$ Metabolizable energy (ME) $=\mathrm{TDN}\left(\mathrm{g} \mathrm{kg}^{-1} \mathrm{DM}\right) \times 4.4 \times 0.82$ (NASEM, 2016).

fed the WSC diet, Angus fed the GC diet, and Angus fed the WSC diet, with nine animals in each treatment.

The experimental diets were offered ad libitum, twice a day, at $07 \mathrm{~h} 30 \mathrm{a} . \mathrm{m}$. and $15 \mathrm{~h} 30 \mathrm{p} . \mathrm{m}$. The experiment lasted for 81 days preceded by 28 days of adaptation to the facilities and diets.

\section{Slaughter, meat collection and analysis}

The Nellore bulls were slaughtered at a final BW of 451.5 $\pm 18 \mathrm{~kg}$ and an average daily gain (ADG) of $1.14 \pm 0.16$ $\mathrm{kg} \mathrm{d}^{-1}$ and Angus bulls were slaughtered at $545.5 \pm 18 \mathrm{~kg}$ of final BW and an ADG of $1.89 \pm 0.16 \mathrm{~kg} \mathrm{~d}^{-1}$ (Carvalho et al., 2016). The slaughter technique used was concussion and exsanguination via the jugular vein followed by hiding removal and evisceration. Twenty-four hours after the carcass cooling at $2{ }^{\circ} \mathrm{C}$, six steaks with $2.54 \mathrm{~cm}$ thickness were collected and sequentially identified for treatment in the following manner: four steaks were individually packaged under vacuum in nylon-polyethylene packages to determine the color, cooking loss, and shear force, with each steak assigned one aging time $(0,7,14$ or 21 days postmortem). The fifth steak was cut into quarters and one part was used for the analysis of ether extract (EE) and fatty acid profiles. The remaining three parts were packaged under vacuum in nylon-polyethylene packages to determine thiobarbituric acid-reactive substances (TBARS) with each steak assigned an aging time $(0,14$, or 42 days postmortem). The last portion of beef was used for sarcomere length and myofibrillar fragmentation index (MFI) analyses at four aging times $(0,7,14$, or 21 days postmortem). Aging storage temperature was $1 \pm 0.5^{\circ} \mathrm{C}$.

\section{Cooking loss}

The cooking loss was performed according to Aroeira et al. (2016). The steaks were weighed and grilled at 160$180^{\circ} \mathrm{C}$ until their center reached an internal temperature of $71{ }^{\circ} \mathrm{C}$ (AMSA, 1995). After temperature stabilization, the steaks were weighed and cooking loss was calculated as a percentage of the weight of the steaks before the cooking process.

\section{Shear force}

Shear force was analyzed using the Warner-Bratzler square shear force method (2015). Six rectangular core samples $(1.0 \times 1.0 \times 2.5 \mathrm{~cm})$ were manually removed from each steak parallel to the muscle fibers. The core was completely sheared perpendicular to the muscle fibers in the TA. XT plus texture meter with WarnerBratzler blade of a $1.016 \mathrm{~mm}$ and $200 \mathrm{~mm} \mathrm{~min}^{-1}$ of speed. The maximum force (N) was measured and the average value was calculated for each steak.

\section{Myofibrillar fragmentation index (MFI)}

The MFI was analyzed using the protocol described by Olson and Stromer (1976), with modifications described by Culler et al. (1978). An aliquot of the myofibril suspension was diluted with an extraction solution until reaching a protein concentration of $0.5 \pm 0.05 \mathrm{mg} \mathrm{mL}^{-1}$, determined by the biuret method. The diluted myofibril suspension was measured in an optical density at $540 \mathrm{~nm}$ in a Genesys 10-UV spectrophotometer. The MFI of each steak was obtained by multiplying absorbance by 200 .

\section{Sarcomere length}

The sarcomere length analysis was carried out using the procedure described by Koolmees et al. (1986), with modifications reported by Aroeira et al. (2016). Muscle fillets with $2.5 \times 1.0 \times 1.0 \mathrm{~cm}$ were placed in Eppendorf tubes containing $0.2 \mathrm{M}$ sucrose $0.1 \mathrm{M} \mathrm{NaHPO} 4$ buffer and frozen at $-20^{\circ} \mathrm{C}$. After thawing, the samples were placed 
in laminas and the sarcomere length was determined by helium laser diffraction, as described by Cross et al. (1981), using the average of 18 laminas per sample.

\section{Ether extract and fatty acids analyses}

The beef ether extract (EE) was determined in the lyophilized sample and analyzed according to the method 920.85 of the Association of Official Analytical Chemists ((AOAC), 1990).

For the fatty acid profile, the lipids were extracted using chloroform and methanol $(2: 1, \mathrm{v} / \mathrm{v})$ according to the procedures established by Folch et al. (1957). The samples were esterified in a methanolic sulfuric acid solution according to the methodology described by Hartman and Lago (1973).

A $1-\mu \mathrm{L}$ aliquot of the esterified samples was injected into an Agilent 7890A gas chromatograph equipped with an automatic injector and flame ionization detector. We used a $100 \mathrm{~m}$ SLB-IL111 column with $100 \mathrm{~m} \times 0.25 \mu \mathrm{m}$ internal diameter and $0.20 \mu \mathrm{m}$ film thickness. The samples were quantified according to temperature programming described by Delmonte et al. (2011). Reference mixtures (37-component FAME mix, conjugated $(9 \mathrm{Z}, 11 \mathrm{E})$, linoleic, and conjugated $(10 \mathrm{E}, 12 \mathrm{Z})$ linoleic acid; Sigma-Aldrich, St. Louis, MO, USA) were used to identify peaks. The fatty acids were expressed in grams of individual fatty acids per 100 grams of total fatty acids $\left(\mathrm{g} 100 \mathrm{~g}^{-1}\right)$.

\section{Thiobarbituric acid-reactive substances (TBARS)}

The TBARS were determined according to Tarladgis et al. (1960). Ten grams of meat was ground with $50 \mathrm{~mL}$ of distilled water. After homogenization, we added 0.2 $\mathrm{mL}$ of butylated hydroxytoluene antioxidant $(0.03 \%)$ and $50 \mathrm{~mL}$ of $\mathrm{HCl}$ solution (4M). Afterward, the samples were distilled in a blanket heater at $100{ }^{\circ} \mathrm{C}$, then, $5 \mathrm{~mL}$ of distillate was transferred to a test tube, and $5 \mathrm{~mL}$ of thiobarbituric acid $(0.02 \mathrm{M})$ was added. Subsequently, the test tubes were kept in a boiling water bath (Kacil, Recife, $\mathrm{PE}$, Brazil) for $35 \mathrm{~min}$. The absorbance was measured at $530 \mathrm{~nm}$ in a spectrophotometer and multiplied by 7.8 to obtain the TBARS value, expressed as $\mathrm{mg}$ malonaldehyde $\mathrm{kg}^{-1}$ of meat.

\section{Instrumental color analysis}

The instrumental color analysis was performed on the surface of the steaks at each aging time using a CM-700 spectrophotometric colorimeter and the CIELAB system with an $8 \mathrm{~mm}$ aperture, illuminant $\mathrm{A}$, and $10^{\circ}$ observer angle. Before the color readings, each steak was removed from the vacuum package and exposed to atmospheric air for $30 \mathrm{~min}$ for blooming and oxygenation of myoglobin.

The $\mathrm{L}^{*}, \mathrm{a}^{*}$, and $\mathrm{b}^{*}$ components were recorded using an average of five readings per each steak, taken from the SCE mode. The polar coordinates chroma $\left(\mathrm{C}^{*}\right)$ and hue angle $\left(\mathrm{h}^{*}\right)$ were also determined as: $\mathrm{C}^{*}=\left[\left(\mathrm{a}^{*}\right)^{2}+\right.$ $\left.\left(b^{*}\right)^{2}\right] \times 0.5$ and $h^{*}=\tan ^{-1}\left(b^{*} / a^{*}\right)$.

\section{Statistical analysis}

The EE and fatty acid profile were analyzed using the PROC MIXED in SAS (Statistical Analysis System, version 9.2) with diet, breed, and diet*breed interaction as fixed effects and animals as a random effect.

Cooking loss, shear force, sarcomere length, MFI, color, and lipid oxidation were analyzed using the PROC MIXED in SAS (Statistical Analysis System, version 9.2), through the model:

$Y_{i j k}=\mu+D_{i}+B_{j}+T_{k}+(B D)_{i j}+(D T)_{i k}+(B T)_{j k}+(D B T)$ ${ }_{i j k}+e_{i j k}$

where: $Y_{i j k}$ are the observed values, $\mu$ is the overall mean, $D i$ is the ith level of the fixed effect of diet (two levels), $B_{j}$ is the $j$ th level of the fixed effect of breed (two levels), $T_{k}$ is the $k$ th level of the fixed effect of aging time (four levels), and $e_{\mathrm{ijk}}$ is the random error associated with $Y_{i j k}$.

The covariance structure with the smallest Bayesian information criterion was used in the analysis. Treatments were compared using the Fisher's Protected Least Significant Difference and the least square means statement was used to calculate the means adjusted for treatments. The SLICE function of SAS was used to determine simple effects within time. Statistical significance was declared at $p \leq 0.05$ and tendencies were defined as $0.05<p \leq 0.10$.

\section{Results}

\section{Cooking loss, myofibrillar fragmentation index, sarcomere length, and shear force}

There was no effect of breed $\times$ diet $\times$ aging time $(p=$ $0.55)$, breed $\times$ diet $(p=0.12)$, diet $(p=0.59)$ or breed $(p$ $=0.80$ ) on cooking loss (Table 2). Additionally, cooking loss, shear force, MFI, and sarcomere length were not influenced by breed $\times$ diet $\times$ aging time $(p \geq 0.25)$, breed $\times$ aging time $(p \geq 0.18)$, and diet $\times$ aging time $(p \geq 0.36)$, and breed $\times \operatorname{diet}(p \geq 0.40)$ (Figure 1). Although there was no effect of diet $(p \geq 0.24)$, beef from Angus bulls had a lower shear force value $(p<0.01)$, greater MFI $(p=0.04)$ and sarcomere length $(p<0.01)$ compared to Nellore beef (Figure 1).

The aging time affected all variables, regardless of diet and breed. The shear force $(p<0.01)$ and sarcomere length $(p \leq 0.02)$ decreased with aging time, whereas MFI increased with aging time $(p<0.01)$ (Figure 1). Furthermore, there was a quadratic effect of aging time on cooking loss, with a greater loss at 17 days $(p<0.01$; Figure 2).

\section{Total lipid and Fatty acid profile}

The longissimus muscles of Angus bulls had greater EE 
Table 2 - Cooking loss (CL) and color parameters of beef from young Nellore and Angus bulls fed ground corn or whole shelled corn diets.

\begin{tabular}{|c|c|c|c|c|c|c|c|c|c|}
\hline \multirow{2}{*}{ Variables } & \multicolumn{2}{|c|}{ Angus } & \multicolumn{2}{|c|}{ Nellore } & \multirow{2}{*}{ SEM } & \multicolumn{4}{|c|}{$p$-values } \\
\hline & $\mathrm{GC}$ & WSC & GC & WSC & & Breed & Diet & $B * D$ & $B * D * A$ \\
\hline $\mathrm{CL}(\%)$ & 26.6 & 27.6 & 27.8 & 26.0 & 0.82 & 0.80 & 0.59 & 0.12 & 0.55 \\
\hline Ligthness (L*) & 49.7 & 49.2 & 50.9 & 48.8 & 0.75 & 0.78 & 0.16 & 0.35 & 0.19 \\
\hline Redness $\left(a^{\star}\right)$ & 14.0 & 14.0 & 13.8 & 13.9 & 0.47 & 0.76 & 0.84 & 0.95 & 0.90 \\
\hline Yellowness $\left(b^{*}\right)$ & 10.2 & 10.1 & 10.3 & 10.2 & 0.36 & 0.66 & 0.78 & 0.97 & 0.77 \\
\hline Chroma $\left(C^{*}\right)$ & 17.3 & 17.4 & 17.2 & 17.3 & 0.58 & 0.97 & 0.98 & 0.95 & 0.85 \\
\hline Hue angle $\left(h^{*}\right)$ & 36.1 & 35.8 & 36.9 & 36.2 & 0.31 & 0.06 & 0.13 & 0.57 & 0.25 \\
\hline
\end{tabular}

$\mathrm{GC}=$ ground corn; WSC $=$ whole shelled corn; $\mathrm{SEM}=$ Standard error of the mean.; $B^{*} D=$ breed $^{*}$ diet interaction; $B^{*} D^{*} A=$ breed $^{*}$ diet ${ }^{\star}$ aging time interaction .

contents compared to the muscles of Nellore bulls (diet $(p=0.05)$. Neither diet $(p=0.89)$ nor breed $\times$ diet interaction $(p=0.27)$ affected this variable (Table 3).

There was a greater $(p<0.01)$ concentration of palmitic acid (C16:0) in the LT muscle of Nellore bulls, regardless of diet (Table 3). On the other hand, Angus bulls had a greater content of linoleic acid (C18:2n6) $(p<0.01)$, PUFA $(p<0.01)$ and omega-6 fatty acids $(p<0.001)$. There was breed $\times$ diet interaction for concentration of five fatty acids in the longissimus muscle. Concentrations of myristic $(\mathrm{C} 14: 0)$ and stearic acids (C18:0) did not differ when Nellore bulls were fed GC or WSC diets, but when Angus bulls were fed WSC, their muscle had a greater proportion of these fatty acids $(p \leq$ 0.04). In contrast, the concentration of $\alpha$-linolenic acid (C18:3n3) did not differ in Angus bulls fed GC or WSC, but increased when Nellore bulls were fed a WSC diet $(p=0.02)$. The concentrations of pentadecanoic (C15:0) $(p=0.03)$ and myristoleic acids $(\mathrm{C} 14: 1)(p=0.01)$ were greater in Angus fed the WSC diet; however, in Nellore muscle, C15:0 concentration was greater for bulls fed WSC and C14:1 concentration was lower in Nellore bulls fed WSC ( $p \leq 0.03)$.

Regardless of the breed, the LT muscle of bulls fed WSC had greater concentrations of linoleic acid $(p$ $=0.02)$ and $\mathrm{C} 18: 2 \mathrm{t} 10 \mathrm{c} 12(p=0.01)$ and tended to have an increased concentration of C18:2c9t11 $(p=0.09)$ and $\mathrm{C} 18: 1$ trans isomers $(p=0.08)$. However, it was not possible to separate C18:1 trans isomers. Furthermore, bulls fed WSC had greater concentrations of PUFA ( $p$ $=0.05)$ and omega- 6 fatty acids $(p=0.03)$, and lower contents of $\mathrm{C} 16: 0(p<0.001)$.

\section{TBARS and colors}

Regardless of the breed, beef from animals fed WSC tended to have greater TBARS values than animals fed GC $(p=0.06)$, and TBARS values also increased with aging time $(p<0.01$; Figure 3$)$. For color components, diet and breed did not affect $\mathrm{L}^{*}, \mathrm{a}^{*}, \mathrm{~b}^{*}$ and $\mathrm{C}^{*}(p \geq 0.16$; Table 2). However, Nellore beef tended to have a greater $\mathrm{h}^{*}$ value $(p=0.06)$. Furthermore, the $\mathrm{h}^{*}$ value was not affected by aging time $(p=0.65)$. On the other hand, aging time affected $\mathrm{L}^{*}(p=0.04), \mathrm{a}^{*}(p<0.01), \mathrm{b}^{*}(p$ $<0.01)$ and $\mathrm{C}^{*}(p<0.01)$, regardless of breed and diet (Figure 4). An increase in $\mathrm{L}^{*}, \mathrm{a}^{*}, \mathrm{~b}^{*}$ and $\mathrm{C}^{*}$ was observed with aging time, but after 14 days of aging, $a^{*}, b^{*}$ and $C^{*}$ started to decrease, whereas the $\mathrm{L}^{*}$ value kept increasing with less intensity. Additionally, there was no effect of the breed $\times$ diet $\times$ aging time interaction for TBARS $(p=$ $0.17)$ and color components $(p \geq 0.19)$.

\section{Discussion}

Tenderness is highly affected by myofibrillar proteolysis that remains active in the muscle post-mortem. The enzyme activity of the proteolytic systems can be indirectly measured by the MFI and can predict over 50 $\%$ of the variation in beef tenderness (Warriss, 2010). In our study, beef from Angus bulls had lower shear force regardless of aging time and had a greater MFI compared to Nellore beef. Considering a $53 \mathrm{~N}$ threshold for tender meat (Silva et al., 2015), on the $14^{\text {th }}$ aging day (shear force equal $50.10 \mathrm{~N}$ ) the beef, regardless of the treatment, could be considered tender.

Sarcomere length also contributes to the variation in beef tenderness. A reduction in the sarcomere length overall leads to an increase in shear force, decreasing tenderness (Starkey et al., 2016), as it was found in our study. Intramuscular fat may increase beef tenderness because fat dilutes the effects of tougher myofibrillar elements or reduces rigidity of the muscle structure (Warriss, 2010) or due to a decrease in muscle density (Karlsson et al., 1999). In our study, the Angus beef had more intramuscular fat, which supports greater meat tenderness of this breed.

Another important characteristic related to beef quality is the fatty acid profile, as it plays an important role in oxidative stability during the cooking process, affecting taste (Wood et al., 2008). The WSC diet had a greater concentration of linoleic acid than GC diet (Table 1), and this fatty acid could be hydrogenated by microorganisms to produce stearic acid. However, the rumen $\mathrm{pH}$ of the bulls fed the WSC diet was lower (5.74 and 6.22, $p=0.03$ ) (Carvalho et al., 2016), which could increase the population of Megasphaera elsdenii and the Propionibacterium acnes in the rumen resulting in incomplete biohydrogenation and accumulation of C18:2t10c12 from linoleic acid as observed by Kim et al. (2002) and McKain et al. (2010). The fact that bulls fed the WSC diet tended to have greater concentrations of biohydrogenation intermediates C18:2c9t11 and C18:1 trans in our study is consistent with changes in the rumen microbial population. 

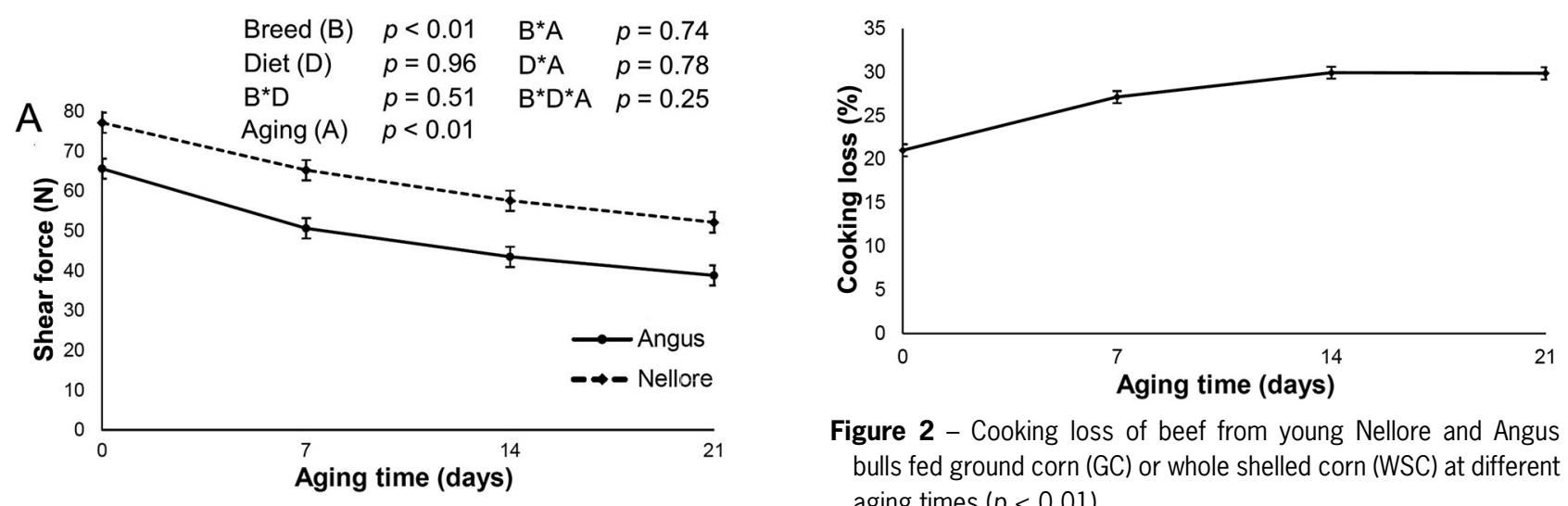

Figure 2 - Cooking loss of beef from young Nellore and Angus bulls fed ground corn (GC) or whole shelled corn (WSC) at different aging times $(p<0.01)$.
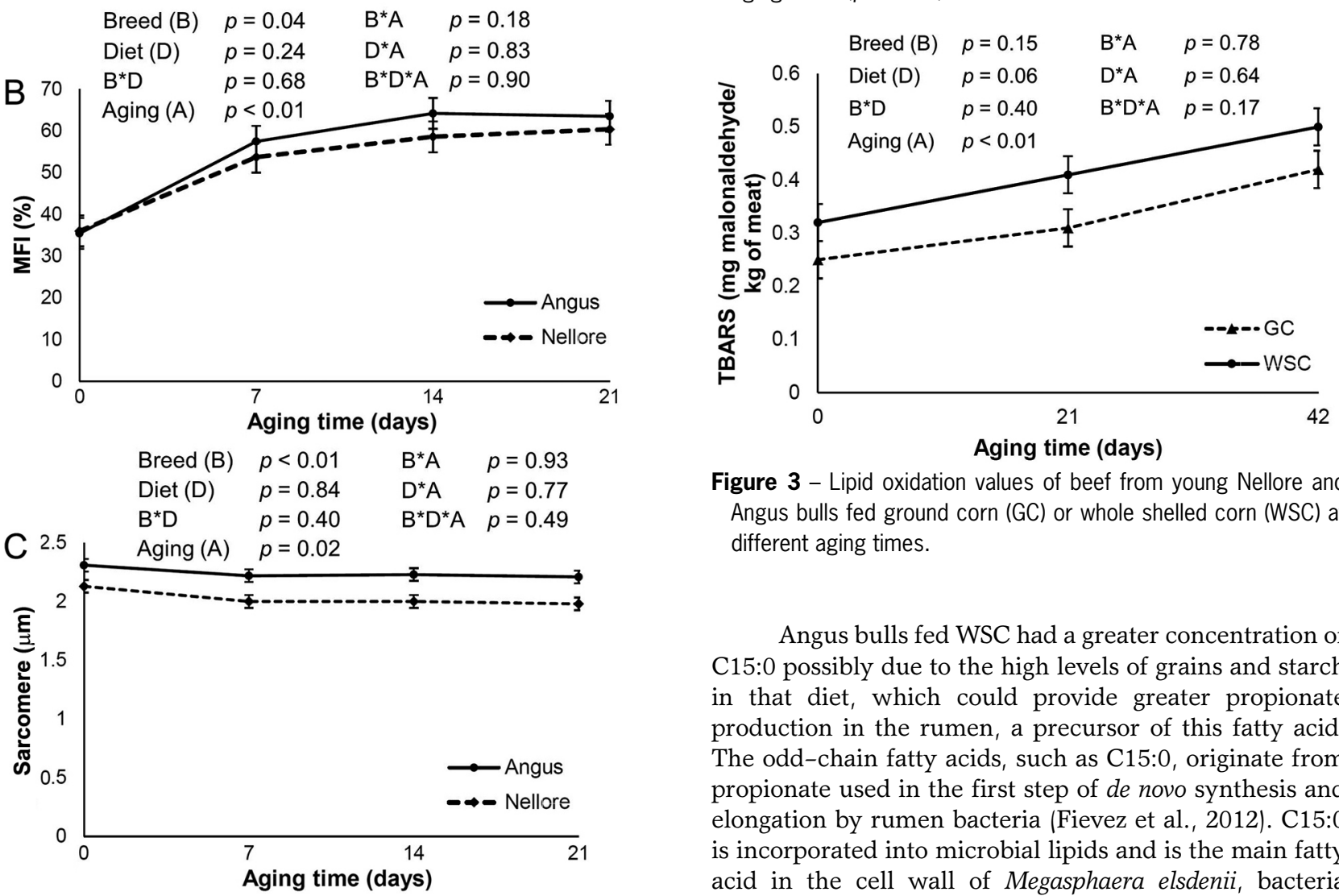

Figure 3 - Lipid oxidation values of beef from young Nellore and Angus bulls fed ground corn (GC) or whole shelled corn (WSC) at different aging times.

Angus bulls fed WSC had a greater concentration of C15:0 possibly due to the high levels of grains and starch in that diet, which could provide greater propionate production in the rumen, a precursor of this fatty acid. The odd-chain fatty acids, such as C15:0, originate from propionate used in the first step of de novo synthesis and elongation by rumen bacteria (Fievez et al., 2012). C15:0 is incorporated into microbial lipids and is the main fatty acid in the cell wall of Megasphaera elsdenii, bacteria that increases its population when the rumen $\mathrm{pH}$ is low (Fievez et al., 2012).

Feeding WSC to Angus increased the concentration of C14:0 compared to feeding GC. However, feeding WSC to Angus also increased the C18:0 content compared to the GC diet, and accounted for approximately $40 \%$ of the total saturated fatty acids in the longissimus muscle. The greater amount of C18:0 may have been obtained by elongation of palmitic acid (C16:0), the main fatty acid product formed by the de novo synthesis. The reduction of C16:0 in these animals is consistent with an increased conversion to C18:0. Feeding WSC to Nellore resulted in a greater concentration of $\mathrm{C} 18: 3 \mathrm{n} 3$ in the beef compared to feeding GC. Alpha-linolenic acid (C18:3n3) is a fatty acid exclusively of dietary origin. Millen et al. (2015) observed 
Table 3 - Ether extract and composition of main fatty acids (\%) present in the muscle of young Nellore and Angus bulls fed ground corn or whole shelled corn diets.

\begin{tabular}{|c|c|c|c|c|c|c|c|c|c|}
\hline & \multicolumn{2}{|c|}{ Angus } & \multicolumn{2}{|c|}{ Nellore } & \multirow[b]{2}{*}{ SEM } & \multicolumn{3}{|c|}{ p-values } \\
\hline & & GC & WSC & GC & WSC & & Breed & Diet & $B^{*} D$ \\
\hline Ether extract (\%) & & 4.79 & 5.10 & 4.51 & 4.11 & 0.39 & 0.05 & 0.89 & 0.27 \\
\hline \multicolumn{10}{|l|}{ Fatty acids } \\
\hline Lauric & $\mathrm{C} 12: 0$ & 0.56 & 0.54 & 0.56 & 0.63 & 0.08 & 0.56 & 0.71 & 0.55 \\
\hline Myristic & $\mathrm{C} 14: 0$ & $3.98^{\mathrm{b}}$ & $7.53^{\mathrm{a}}$ & $4.97^{b}$ & $4.06^{b}$ & 0.79 & 0.12 & 0.01 & $<0.001$ \\
\hline Myristoleic & $\mathrm{C} 14: 1$ & $0.92^{c}$ & $1.56^{\mathrm{ab}}$ & $1.74^{\mathrm{a}}$ & $1.10^{\mathrm{bc}}$ & 0.25 & 0.46 & 0.99 & 0.01 \\
\hline Pentadecanoic & $\mathrm{C} 15: 0$ & $0.55^{d}$ & $1.18^{\mathrm{a}}$ & $0.66^{\mathrm{cd}}$ & $0.85^{b}$ & 0.10 & 0.25 & $<0.001$ & 0.03 \\
\hline Palmitic & C16:0 & 25.9 & 14.6 & 30.8 & 24.7 & 2.19 & $<0.01$ & $<0.001$ & 0.22 \\
\hline Palmitoleic & C16:1 & 4.09 & 5.76 & 4.10 & 3.37 & 0.85 & 0.13 & 0.54 & 0.13 \\
\hline Margaric & $\mathrm{C} 17: 0$ & 1.73 & 2.51 & 1.42 & 1.61 & 0.39 & 0.12 & 0.20 & 0.44 \\
\hline Stearic & $\mathrm{C} 18: 0$ & $14.6^{b}$ & $20.4^{a}$ & $18.6^{\mathrm{ab}}$ & $14.8^{\mathrm{b}}$ & 2.66 & 0.64 & 0.58 & 0.04 \\
\hline Trans octadecenoic ${ }^{1}$ & $\mathrm{C} 18: 1$ trans & 2.29 & 3.30 & 1.93 & 2.75 & 0.44 & 0.37 & 0.08 & 0.85 \\
\hline Oleic & C18:1c9 & 29.6 & 27.0 & 29.3 & 34.7 & 3.65 & 0.22 & 0.64 & 0.18 \\
\hline Linoleic & $\mathrm{C} 18: 2 \mathrm{n} 6$ & 8.12 & 9.93 & 5.17 & 7.47 & 0.85 & $<0.01$ & 0.02 & 0.76 \\
\hline CLA & C18:2c9t11 & 0.40 & 0.69 & 0.55 & 0.62 & 0.11 & 0.71 & 0.09 & 0.31 \\
\hline CLA & C18:2t10c12 & 0.14 & 0.17 & 0.14 & 0.18 & 0.01 & 0.96 & 0.01 & 0.68 \\
\hline$\alpha$ Linolenic & $\mathrm{C} 18: 3 \mathrm{n} 3$ & $0.43^{\mathrm{ab}}$ & $0.22^{\mathrm{b}}$ & $0.22^{b}$ & $0.52^{\mathrm{a}}$ & 0.11 & 0.64 & 0.67 & 0.02 \\
\hline Arachidonic & $\mathrm{C} 20: 4 n 6$ & 1.20 & 1.43 & 0.99 & 1.17 & 0.19 & 0.24 & 0.31 & 0.89 \\
\hline EPA & C20:5n3 & 0.08 & 0.06 & 0.09 & 0.06 & 0.04 & 0.87 & 0.55 & 0.99 \\
\hline DPA & $\mathrm{C} 22: 6 n 3$ & 0.22 & 0.24 & 0.19 & 0.23 & 0.04 & 0.73 & 0.46 & 0.79 \\
\hline$\sum$ Saturated & & 49.6 & 48.6 & 54.7 & 47.7 & 4.40 & 0.51 & 0.26 & 0.48 \\
\hline$\sum$ Unsaturated & & 50.4 & 51.4 & 45.3 & 52.3 & 4.28 & 0.60 & 0.31 & 0.46 \\
\hline$\Sigma$ UFA/SFA & & 1.01 & 1.06 & 0.83 & 1.10 & 0.36 & 0.35 & 0.26 & 0.63 \\
\hline$\sum$ Monounsaturated & & 37.7 & 35.6 & 35.8 & 40.9 & 4.57 & 0.69 & 0.71 & 0.40 \\
\hline$\sum$ Polyunsaturated & & 12.7 & 15.8 & 9.58 & 11.4 & 1.29 & $<0.01$ & 0.05 & 0.58 \\
\hline$\sum$ Omega-3 & & 0.93 & 0.88 & 0.82 & 0.77 & 0.14 & 0.40 & 0.69 & 0.98 \\
\hline$\sum$ Omega-6 & & 10.7 & 13.5 & 7.59 & 9.3 & 1.16 & $<0.001$ & 0.03 & 0.57 \\
\hline 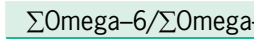 & & 11.5 & 15.3 & 9.26 & 12.1 & 3.26 & 0.153 & 0.63 & 0.67 \\
\hline
\end{tabular}

$\mathrm{GC}=$ ground corn; $\mathrm{WSC}=$ whole shelled corn; $\mathrm{SEM}=$ Standard error of the mean.; $\mathrm{B}^{*} \mathrm{D}=$ breed ${ }^{*}$ diet interaction; $\mathrm{CLA}=$ Conjugated Linoleic Acid; $\mathrm{EPA}=$ eicosapentaenoic acid; DPA = docosapentaenoic acid; UFA/SFA = Unsaturated / Saturated fatty acids. 1 Sum of C18:1trans (C18:1 trans 9, C18:1 trans 10, C18:1 trans 11); a,b,c,d Values within a row with different superscripts differ significantly according to the Tukey test.
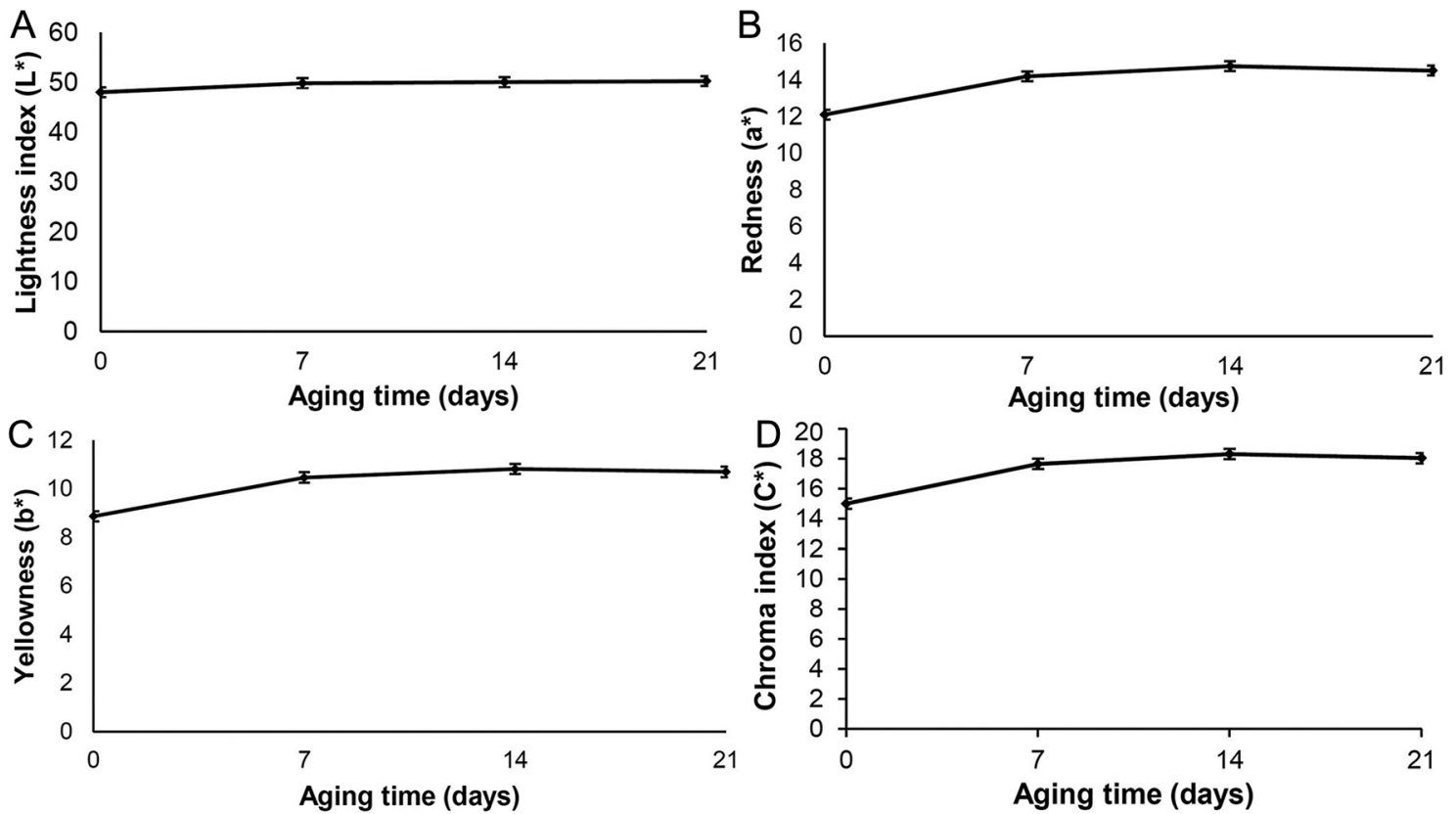

Figure $4-L^{*}(A ; p=0.04), a^{*}(B ; p<0.01), b^{*}(C ; p<0.01) C^{*}(D ; p<0.01)$ indices of beef from young Nellore and Angus bulls fed ground corn (GC) or whole shelled corn (WSC) diets at different aging times. 
that Zebu cattle develop ruminal problems due to the low $\mathrm{pH}$ more frequently when consuming high-concentrate diets compared to Taurine cattle, which could mean that Nellore bulls had less capacity to biohydrogenate the linolenic acid. In this sense, Angus bulls had more capacity for biohydrogenation, leading the WSC diet to increase stearic acid compared to GC diet.

Angus bulls had a greater PUFA concentration than Nellore bulls, in contrast to previous results reported in the literature, which demonstrated that steers with greater intramuscular fat produce beef with lower PUFA concentrations (Aldai et al., 2006, De Smet et al., 2004; Nfor et al., 2014). The greater deposition of PUFA and $\mathrm{n}-6$ in Angus is explained by the greater concentration of C18:2n6 in the muscles of these animals, which might be due to lower biohydrogenation in Angus than in Nellore. We previously reported that Angus bulls had a greater passage rate $\left(4.74 \% \mathrm{~h}^{-1}\right.$ and $\left.3.20 \% \mathrm{~h}^{-1}, p<0.01\right)$ (Carvalho et al., 2016) compared to Nellore, which could lead to decreased biohydrogenation and increased linoleic acid in the muscle.

Regarding the dietary effects, bulls fed the WSC diet had greater muscle concentrations of PUFA, linoleic acid, and n-6 fatty acids compared to bulls fed GC, which could be attributed to the greater PUFA concentration and linoleic acid contents in the WSC diet. Additionally, we suggested that the ruminal biohydrogenation reduced when the WSC diet was fed, due to the lower rumen $\mathrm{pH}$, which may have helped increase these fatty acids. The tendency for high TBARS values in the muscle of animals fed the WSC diet corroborates the results for fatty acids. According to Wood et al. (2008), PUFA in phospholipids is vulnerable to an oxidative breakdown that decreases oxidative stability during processing and retail display. Although the muscles of animals fed the WSC diet had high levels of lipid oxidation, this may not be enough to affect the beef taste until 21 days of aging time. As stated to Tarladgis et al. (1960) TBARS values of approximately $0.5 \mathrm{mg}$ of malonaldehyde $\mathrm{kg}^{-1}$ of meat may be considered the limit for acceptable meat. Above this threshold value, consumers can detect rancid odor and taste due to lipid oxidation products. The threshold of $0.5 \mathrm{mg}$ was reached only after 42 days of storage for beef of animals fed WSC and could be a problem when the beef stays for a long time in the meat display, as observed in supermarkets in Brazil. Color indices corroborate the idea that taste and odor were minimally impacted. Changes occurred in fatty acids due to diets or breeds; however, they were not enough to have a negative effect on myoglobin color or lipid oxidation.

In conclusion, Angus bulls produce beef with greater tenderness and concentration of PUFA than Nellore bulls. Additionally, fatty acid profile differed between Nellore and Angus, but some differences between breeds depended on the feedlot diet. Additionally, the results for fatty acids show a possible change in biohydrogenation when the animals are fed the WSC diet, resulting in reduced lipogenesis as it increases the C18:2t10c12 content.

\section{Acknowledgments}

The authors would like to thank Minas Gerais State Agency for Research and Development (FAPEMIG), (Belo Horizonte, Minas Gerais, Brazil) (grant number: CVZ-APQ-04752-10), National Institute of Science and Technology in Animal Science (INCT) (Viçosa, Minas Gerais, Brazil), Coordination for the Improvement of Higher Education Personnel (CAPES) (grant number: 001), Brazilian National Council for Scientific and Technological Development (CNPq) (grant number: 305076/2017-5) and Cargill (Itapira, São Paulo, Brazil) for funding this study.

\section{Authors' Contributions}

Conceptualization: Ladeira, M.M. Data acquisition: Teixeira, P.D; Carvalho, J.R.R. Data analysis: Teixeira, P.D; Carvalho, J.R.R.; Oliveira, C.V.R.; Rodrigues, A.C.; Santos, L.R. Design of methodology: Ladeira, M.M; Schoonmaker, J.P. Writing and editing: Teixeira, P.D.; Ladeira, M.M; Schoonmaker J.P.

\section{References}

Association of Official Analysis Chemists - International [AOAC]. 1990. Official Methods of Analysis. 15ed. Arlington, VA, USA.

Aldai, N.; Murray, B.E.; Oliván, M.; Martínez, A.; Troy, D.J.; Osoro, K.; Nájera, A.I. 2006. The influence of breed and mh-genotype on carcass conformation, meat physico-chemical characteristics, and the fatty acid profile of muscle from yearling bulls. Meat Science 72: 486-495.

American Meat Science Association [AMSA]. 1995. Research Guidelines for Cookery, Sensory Evaluation, and Instrumental Tenderness Measurements of Fresh Meat. AMSA, Chicago, IL, USA.

Andrade, P.L.; Bressan, M.C.; Gama, L.T.; Gonçalves, T.M.; Ladeira, M.M.; Ramos, E. M. 2010. Aged meat quality in Red Norte and Nellore cattle. Revista Brasileira de Zootecnia 39: 1791-1800 (in Portuguese, with abstract in English).

Aroeira, C.N.; Torres Filho, R.A.; Fontes, P.R.; Gomide, L.A.M.; Ramos, A.L.S.; Ladeira, M.M.; Ramos, E.M. 2016. Freezing, thawing and aging effects on beef tenderness from Bos indicus and Bos taurus cattle. Meat Science 116: 118-125.

Barcellos, V.C.; Mottin, C.; Passetti, R.A.C.; Guerrero, A.; Eiras, C.E.; Prohman P.E.; Vital, A.C.P.; Prado, I.N. 2017. Carcass characteristics and sensorial evaluation of meat from Nellore steers and crossbred Angus vs. Nellore bulls. Acta Scientiarum. Animal Sciences 39: 437-448.

Bressan, M.C.; Rodrigues, E.C.; Paula, M.L.; Ramos, E.M.; Portugal, P.V.; Silva, J.S.; Bessa, R.B.; Gama, L.T. 2016. Differences in intramuscular fatty acid profiles among Bos indicus and crossbred Bos taurus $\times$ Bos indicus bulls finished on pasture or with concentrate feed in Brazil. Italian Journal of Animal Science 15: 10-21.

Bressan, M.C.; Rossato, L.V.; Rodrigues, E.C.; Alves, S.P.; Bessa, R.J.B.; Ramos, E.M.; Gama, L.T. 2011. Genotype $\times$ environment interactions for fatty acid profiles in Bos indicus and Bos taurus finished on pasture or grain. Journal of Animal Science 89: 221-232. 
Carvalho, J.R.; Chizzotti, M.L.; Schoonmaker, J.P.; Teixeira, P.D.; Lopes, R.C.; Oliveira, C.V.R.; Ladeira, M.M. 2016. Performance, carcass characteristics, and ruminal $\mathrm{pH}$ of Nellore and Angus young bulls fed a whole shelled corn diet. Journal of Animal Science 94: 2451-2459.

Cross, H.R.; West, R.L.; Dutson, T.R. 1981. Comparison of methods for measuring sarcomere length in beef semitendinosus muscle. Meat Science 5: 261-266.

Culler, R.D.; Parrish, F.C.; Smith, G.C.; Cross, H.R. 1978. Relationship pf myofibril fragmentation index to certain chemical, physical and sensory characteristics of bovine longissimus muscle. Journal of Food Science 43: 1177-1180.

De Smet, S.; Raes, K.; Demeyer, D. 2004. Meat fatty acid composition as affected by fatness and genetic factors: a review. Animal Research 53: 81-98.

Delmonte, P.; Fardin Kia, A. -R.; Kramer, J.K.G.; Mossoba, M.M.; Sidisky, L.; Rader, J.I. 2011. Separation characteristics of fatty acid methyl esters using SLB-IL111, a new ionic liquid coated capillary gas chromatographic column. Journal of Chromatography A 1218: 545-554.

Fievez, V.; Colman, E.; Castro-Montoya, J.M.; Stefanov, I.; Vlaeminck, B. 2012. Milk odd- and branched-chain fatty acids as biomarkers of rumen function: an update. Animal Feed Science and Technology 172: 51-65.

Folch, J.; Lees, M.; Sloane-Stanley, G. 1957. A simple method for the isolation and purification of total lipids from animal tissues. Journal of Biological Chemistry 226: 497-509.

Hartman, L.; Lago, R.1973. Rapid preparation of fatty acid methyl esters from lipids. Laboratory Practice 22: 475-476 passim.

Jenkins, T.C.; Harvatine, K.J. 2014. Lipid feeding and milk fat depression. Veterinary Clinics: Food Animal Practice 30: 623-642.

Karlsson, A.H.; Klont, R.E.; Fernandez, X. 1999. Skeletal muscle fibres as factors for pork quality. Livestock Production Science 60: 255-269.

Kim, Y.; Liu, R.; Rychlik, J.; Russell, J. 2002. The enrichment of a ruminal bacterium (Megasphaera elsdenii YJ-4) that produces the trans-10, cis-12 isomer of conjugated linoleic acid. Journal of Applied Microbiology 92: 976-982.

Koolmees, P.A.; Korteknie, F.; Smulders, F.J.M. 1986. Accuracy and utility of sarcomere length assessment by laser diffraction. Food Microstructure 5: 71-76.

Ladeira, M.M.; Santarosa, L.C.;Chizzotti, M.L.; Ramos, E.M.; Machado Neto, O.R.; Oliveira, D.M.; Carvalho, J.R.R.; Lopes, L.S.; Ribeiro, J.S. 2014. Fatty acid profile, color and lipid oxidation of meat from young bulls fed ground soybean or rumen protected fat with or without monensin. Meat Science 96: 597-605.

Ladeira, M.M.; Schoonmaker, J.P.; Swanson, K.C.; Ducket, S.K.; Gionbelli, M.P.; Rodrigues, L.M.; Teixeira, P.D. 2018. Review: nutrigenomics of marbling and fatty acid profile in ruminant meat. Animal 12 (s2): 282-294.

McKain, N.; Shingfield, K.J.; Wallace, R.J. 2010. Metabolism of conjugated linoleic acids and 18: 1 fatty acids by ruminal bacteria: products and mechanisms. Microbiology 156: 579-588.

Millen, D.D.; Pacheco, R.; Di Lorenzo, N.; Martins, C.; Marino, C.T.; Bastos, J.; Mariani, T.; Barducci, R.S.; Sarti, L.; Di Costanzo, A. 2015. Effects of feeding a spray-dried multivalent polyclonal antibody preparation on feedlot performance, feeding behavior, carcass characteristics, rumenitis, and blood gas profile of Brangus and Nellore yearling bulls. Journal of Animal Science 93: 4387-4400.

National Academies of Sciences, Engineering, and Medicine [NASEM] 2016. Nutrient Requirements of Beef Cattle. National Academies Press, Washington, DC, USA.

Nfor, B.M.; Corazzin, M.; Fonteh, F.A.; Sepulcri, A.; Aziwo, N.T.; Piasentier, E. 2014. Fatty acid profile of zebu beef cattle from the Central African sub-region. South African Journal of Animal Science 44: 140-147.

Obsen, T.; Faergeman, N.J.; Chung, S.; Martinez, K.; Gobern, S.; Loreau, O.; Wabitsch, M.; Mandrup, S.; McIntosh, M. 2012. Trans-10, cis-12 conjugated linoleic acid decreases de novo lipid synthesis in human adipocytes. Journal of Nutritional Biochemistry 23: 580-590.

Olson, D.G.; Stromer, M. 1976. Myofibril fragmentation and shear resistance of three bovine muscles during postmortem storage. Journal of Food Science 41: 1036-1041.

Owens, F.N.; Secrist, D.S.; Hill, W.J.; Gill, D.R. 1998. Acidosis in cattle: a review. Journal of Animal Science 76: 275-286.

Rossato, L.V.; Bressan, M.C.; Rodrigues, É.C.; Gama, L.T.; Bessa, R.J.B.; Alves, S.P.A. 2010. Physicochemical parameters and fatty acid profiles in Angus and Nellore cattle finished on pasture. Revista Brasileira de Zootecnia 39: 1127-1134 (in Portuguese, with abstract in English).

Silva, D.R.G.; Torres Filho, R.A.; Cazedey, H.P.; Fontes, P.R.; Ramos, A.L.S.; Ramos, E.M. 2015. Comparison of WarnerBratzler shear force values between round and square crosssection cores from cooked beef and pork Longissimus muscle. Meat Science 103: 1-6.

Sniffen, C.J.; O'Connor, J.D.; Van Soest, P.J.; Fox, D.G.; Russell, J.B. 1992. A net carbohydrate and protein system for evaluating cattle diets: II. Carbohydrate and protein availability. Journal of Animal Science 70: 3562-3577.

Starkey, C.P.; Geesink, G.H.; Collins, D.; Hutton, Oddy V.; Hopkins, D.L. 2016. Do sarcomere length, collagen content, $\mathrm{pH}$, intramuscular fat and desmin degradation explain variation in the tenderness of three ovine muscles? Meat Science 113: 51-58.

Tarladgis, B.G.; Watts, B.M.; Younathan, M.T.; Dugan, L. 1960. A distillation method for the quantitative determination of malonaldehyde in rancid foods. Journal of the American Oil Chemists Society 37 : 44-48.

Teixeira, P.D.; Oliveira, D.M.; Chizzotti, M.L.; Chalfun-Junior, A.; Coelho, T.C.; Gionbelli, M.P.; Paiva, L.V.; Carvalho, J.R.R.; Ladeira, M.M. 2017. Subspecies and diet affect the expression of genes involved in lipid metabolism and chemical composition of muscle in beef cattle. Meat Science 133: 110-118.

Warriss, P.D. 2010. Meat Science: An Introductory Text. CABI, Wallingford, UK.

Wood, J.D.; Enser, M.; Fisher, A.V.; Nute, G.R.; Sheard, P.R.; Richardson, R.I.; Hughes, S.I.; Whittington, F.M. 2008. Fat deposition, fatty acid composition and meat quality: a review. Meat Science 78: 343-358.

Wu, J.H.; Lemaitre, R.N.; Imamura, F.; King, I.B.; Song, X.; Spiegelman, D.; Siscovick, D.S.; Mozaffarian, D. 2011. Fatty acids in the de novo lipogenesis pathway and risk of coronary heart disease: the cardiovascular health study. The American Journal of Clinical Nutrition 94: 431-438. 